\title{
Barriers to broaden the electricity production from biomass and biogas in Brazil
}

\author{
Margareth de Cássia Oliveira Pavan ${ }^{\mathrm{a} *}$ (D), Dorel Soares Ramos ${ }^{\mathrm{a}}$ (D), Munir Yones Soares ${ }^{\mathrm{a}}$ (D), \\ Clara Barufi $^{b}$ (D), Marly Monteiro de Carvalho ${ }^{a}$ (D) \\ ${ }^{a}$ Universidade de São Paulo, Escola Politécnica, São Paulo, SP, Brasil

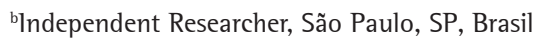 \\ *margaretholiveira@hotmail.com
}

\begin{abstract}
Paper aims: The research aims to identify the main barriers to scaling up the energy production expansion systems from biogas and biomass in Brazil.

Originality: This article aggregates information and different perceptions from a systemic view for bioelectricity production from biomass. It brings to the fore the discussion of bioenergy production from other types of biomass, which encompass a wide range of actors in the production chain.
\end{abstract}

Research method: We adopted a qualitative approach by applying semi-structured interviews with 19 experts from 15 institutions considering various biomass and biogas power generation segments.

Main findings: This paper identifies five barrier categories that restrain or affect the country's broad electricity production from biomass and biogas: circumstantial, cultural, technical, and include other uses of biogas and biomethane. The financial and cultural barriers are the most mentioned by the experts. Financial difficulties of the plants, sector conservatism, issues in the electricity sector, and lack of knowledge limit the potential and interest in developing new projects.

Implications for theory and practice: The results contribute to the development of sectoral public policies as it brings up non-explicit information and reveals broad perspectives aimed at integrating the themes of biogas and biomass. Also, the research adds to the debate on the analysis boundaries of this theme and can support future empirical studies in developing countries that seek to expand renewable sources to power generation from biomass.

Keywords

Biomass. Biogas. Barriers. Sugarcane. Bioelectricity.

How to cite this article: Pavan, M. C. O., Ramos, D. S., Soares, M. Y., Barufi, C., Carvalho, M. M. (2021). Barriers to broaden the electricity production from biomass and biogas in Brazil. Production, 31, e20210064. https://doi.org/10.1590/01036513.20210064

Received: June 2, 2021; Accepted: Oct. 18, 2021.

\section{Introduction}

Brazil has one of the cleanest energy matrices in the world. The high use of hydraulic energy for power generation and the biofuels program are the main reasons the country has a 48.4\% share (in 2020) of renewable sources in its matrix, against an average of $13.8 \%$ in the world (in 2018). Sugarcane biomass, specifically, is responsible for $19.1 \%$ of the total energy used in the country, whether in the form of biofuel (ethanol) or electricity. Particularly considering the electricity matrix, more than $84 \%$ of the electricity used in the country comes from renewable sources (65.2\% from hydroelectric plants). In this context, bioelectricity accounts for 9.1\% of the total (Empresa de Pesquisa Energética, 2021). Note that, in this case, bioelectricity also considers the energy produced from other biomass, such as wood chips and rice husks. 
However, estimates indicate that only $15 \%$ of the bioelectricity potential is used no Brazil. This considering only cogeneration systems installed in sugarcane plants in the country. If the biomass present in the cane fields were fully exploited, bioelectricity would have the technical potential to reach 142 thousand GWh per year. This amount represents almost seven times the volume offered in 2018, which means more than 30\% of the National Connected System (NCS) energy consumption (União da Indústria de Cana-de-Açúcar, 2019).

This potential can be much greater when considering the growth prospects of the Brazilian sugar-energy sector and the feasibility of complementary routes to the traditional cogeneration made from sugarcane bagasse, for instance, the energy generation from biogas produced from by-products (vinasse and filter cake) or other wastes, such as the agricultural industry, sewage treatment systems and urban solid waste.

The Energy Research Company projects that the ethanol supply will grow at $2.4 \%$ a.a. in the next decade, reaching 47 billion litres in 2029 (Empresa de Pesquisa Energética, 2020). The growth in biofuel production has the side effect of increasing waste generation. In addition to bagasse, other residues are produced during alcohol and sugar production, such as vinasse, filter cake and straw.

Vinasse, which results from the ethanol distillation process, consists of 93\% water, 7\% organic solids and minerals. Although there are differences between vinasse samples derived from sugar and/or ethanol production, the volume produced of this waste is 12 litres per litre of ethanol (Christofoletti et al., 2013; Janke et al., 2015). Currently, this by-product is used to fertilise sugarcane plantations, which returns part of the nutrients from the previous harvest to the soil and reduces fertilisation needs (Moraes et al., 2014; Nadaleti et al., 2020). The challenge is that excessive load of vinasse can cause environmental problems, including contamination of the soil and water bodies, stimulating the proliferation of flies (Christofoletti et al., 2013).

Another residue from sugar and alcohol mills production is the filter cake. The filter cake, resulting from the purification of sugarcane juice, is composed of $67 \%$ water, $11,6 \%$ organic matter and 32,9\% other solids. Both wastes (vinasse and filter cake) can be used for biogas production (Frick, 2018).

The biogas can be used in several applications, such as power generation. Also, it can be purified and transformed into biomethane as a substitute for natural gas and diesel and electricity generation (Moraes et al., 2014). Thus, using filter cake and vinasse allows producing biogas 365 days a year (Janke et al., 2015).

Even though the vinasse can only be used during the harvest months, the continuous flow of biogas or power generation is possible, as the filter cake physical characteristics enable its storage. Also, utilising a thermo-chemical or thermal pre-treatment process on filter cake could increase methane production (López González et al., 2014, 2013).

The possibility of biodigestion of both by-products to produce biogas throughout the year, not just harvest time, improves the viability of using this kind of biomass and contributes to a more favourable scenario for power generation from biomass in the future.

Public Policies, such as RenovaBio Policy and a good business environment, can stimulate the network's bioelectricity by more than 50\% in 2027, estimates the Union of the Sugarcane Agroindustry of the State of São Paulo (União da Indústria de Cana-de-Açúcar, 2020). RevonaBio is the National Biofuel Policy instituted by Law No. 13,576/2. This policy aims to meet the commitments determined by Brazil under the Paris Agreement and promote the expansion of biofuels in the energy matrix (Agência Nacional do Petróleo, Gás Natural e Biocombustíveis, 2020).

Also, the Energy Research Company indicates in the Decennial Energy Expansion Plan (PDE 2029) - reference scenario - that the capacity to generate energy from biomass should go from $13.3 \mathrm{GW}$ registered in 2019 to 15.8 GW at the end of the period (Empresa de Pesquisa Energética, 2020). The PDE 2029 is a document aimed at society, indicating the prospects for future expansion of the Brazilian energy matrix in a ten-year horizon. It is translated into essential information for decision-making by potential investors in the energy sector.

Although the scenario is optimistic regarding available resources (biomass) and future estimation, in terms of taking advantage of this available potential, the numbers are still short of the sector's potential. 1t is going from 21.5 GWh in 2018 to 33.2 thousand GWh in 2019, representing the use of only 17\% of the technical potential of the source (União da Indústria de Cana-de-Açúcar, 2019).

Some aspects pointed out in different studies may justify this low expansion of the source given the potential available, such as the difficulty or fear of new investments and the rules of the electricity sector (Ferraresi \& Calia, 2019). Regarding the rules of the electricity sector, the relatively low volume of energy contracted from sugar cane biomass plants in energy auctions to serve the regulated market reflects the difficulties in expanding the generation capacity of the source in the country. For example, the results of the New Energy Auctions (from February 2005 to July 2021) show that of the total contracted (in MWh), only 2.96\% came from sugarcane biomass plants (Câmara de Comercialização de Energia Elétrica, 2021a). 
In the case of power plants, it is worth highlighting the issue of indebtedness in the sector. The low sugar prices and the reduction in the amount of cane crushed in the 2018/2019 harvest led mills to record the secondhighest level of indebtedness in history, only behind the 2015/2016 cycle (Ramos, 2019). The Decennial Plan for Energy Expansion (PDE 2029) highlights that plants indebtedness contributed to decreasing funds raised by the sugar-energy sector from the National Development Bank (BNDES). In 2018, the funds raised by the sector corresponded to about 27\% of those observed in 2013 (Empresa de Pesquisa Energética, 2020).

These situations described can be associated with the challenges of the source to compete with wind and solar energy at auctions. The fact is that, although the price of energy from the three sources has been decreasing in recent years, the decline has been less accelerated in the case of biomass. For instance, biomass cost energy went from R\$ 321 per MWh, in 2015, to R\$ 187 per MWh last year (down 41\%). In the case of wind, the retraction was 58\% on a comparison basis, from R\$ 233 to R\$ 97 per MWh. Solar source, in turn, was also significantly reduced in a shorter time: between 2017 and 2019, the average price decreased from R\$ 155 to R\$ 80 per MWh, a decrease of 48\% (MegaWhat, 2019).

The drop in cost of wind and solar photovoltaic sources in Brazil follows a global trend mainly associated with the fall in equipment production costs and gains in scale in the negotiation of more significant volumes by companies with international operations in solar energy segment. In the specific case of Brazil, there is also an increase in the capacity factor of the projects (also favoured by the availability of larger turbines, in the case of wind power); the development of new sources of financing, including more advantageous and diversified credit lines, and infrastructure debentures as an alternative or complement to BNDES financing; and regulatory factors: energy auctions and long-term contracts have proven to be efficient energy trading mechanisms (Neves, 2018).

Within the context presented above, the present article aims to assess existing barriers in Brazil to conduct the expansion of energy produced from biomass - from sugarcane by-products and other kinds of organic wastes, such as manure, sewage sludge and Urban Solid Waste. Thus, the research aims to answer this question: which barriers impact or restrict electricity production from biomass in Brazil?

Other studies in the literature also addressed the barriers to the expansion of biomass for power generation in Brazil (Hughes et al., 2020; Ferraresi \& Calia, 2019; Mathias \& Mathias, 2015; Mariani, 2018).

Hughes et al., 2020, present the results of semi-structured interviews with 19 representatives of activities related to the sugar-energy sector and identified several barriers for biomass plants not to increase the amount of electricity produced and the export of electricity to the grid, including lack of access to capital, lack of interest, lack of scale in terms of biomass production, distance from the grid and cost reduction of other competing renewable sources, such as wind and solar. Barriers related to Renovabio were also identified, such as a lack of knowledge of certificate prices.

Ferraresi \& Calia (2019), studying the challenges of the sugarcane bioelectricity national electricity market context, pointed out the need for price predictability in the free contracting environment. In addition, the development of specific policies for the sector and the accounting for social and environmental externalities of biomass. Moreover, the researchers emphasised that exclusive auctions for biomass in the regulated contracting environment are essential for the entrepreneur's long-term economic and financial sustainability.

Mathias \& Mathias (2015) also identified a long list of challenges for expanding biogas production in the country, the main one being developing an energy policy that would allow a consistent introduction of the energy source in the electric power matrix in the country. The researcher highlights the importance of governmental agenda centred on legal, political, and regulatory challenges. In this sense, they recommended creating a government agenda that would encourage production for private local consumption to reduce the environmental impacts of waste. In a second phase, excess volumes of biogas or electricity produced from it could be directed to the market, a process that is more complex due to infrastructure restrictions.

Mariani (2018) analysed the barriers to the growth of biogas use in Brazil and discussed the incentive mechanisms that could be applied to overcome them. One of the barriers described by the author was the lack of availability of more efficient technologies for biogas production and energy use since the study indicated a great diversity of plant size, types of substrates used, routes of energy use and distance from the plants concerning installation and maintenance services.

Concerning previous studies that addressed the barriers to expanding bioenergy in Brazil, this article aggregates information and different perceptions from a systemic view for bioelectricity production from biomass. It brings to the fore the discussion of bioenergy production from other types of biomass through the semi-structured interviews, which encompassed a wide range of actors in the production chain, from associations of swine producers to sugar and alcohol mills representatives.

The results thus contribute to the development of sectoral public policies as they bring up non-explicit information and reveals broad perspectives by integrating the themes of biogas and biomass. Moreover, this 
empirical article contributes to the general knowledge about the factors that directly and indirectly impact the development of renewable energies, specifically from biomass in a developing country. By including a broader context in the analysis, the research adds to the debate on the boundaries of analysis of this theme, the results of which can support future empirical studies in developing countries.

This article includes a brief background on factors that impact the expansion of electricity generation from biomass and biogas in Section 1. In this item, we also point out the objectives and the research question and describe the contribution of the present work concerning previous studies that addressed similar issues. Section 2 describes the methodology, and Section 3 brings the results. Section 4 presents the results, and in the last section (Section 5), we conclude with recommendations for future studies.

\section{Methodology}

To answer the research questions "Which barriers impact or restrict electricity production from biomass and biogas in Brazil?" we adopted a qualitative approach, considering the semi-structured interview method by applying questionnaires (Marvasti, 2004; Lune \& Berg, 2017). Apart from semi-structured interviews, secondary data were collected by searching and reviewing articles published, websites, and public or internal documents received from the companies and grey literature through Google and government portals.

This data aimed to provide a broader picture of factors that could impact biomass expansion and corroborate and complement the interviews-this information allowed for interviewers to explore the theme, further accessing the expert knowledge of the interviewees. The semi-structured interviews were carried out with bioelectricity specialists and other actors involved in biogas and bioenergy production and supply chain. Different stakeholders were intentionally incorporated to cover all the agents involved with the topic. This approach allowed us to have a broad view of the problem.

Previous studies have used semi-structured interviews to explore perceptions and knowledge of key actors in contexts relating to energy (Hughes et al., 2020), climate change (Dapeng \& Weiwei, 2009) and waste-toenergy (Donner et al., 2020).

\subsection{Data collection}

The planning of the interviews was carried out in four stages (Lune \& Berg, 2017): (i) information collection, (ii) selection of respondents, (iii) elaboration of the questionnaire, and (iv) conducting interviews, as shown in Figure 1 and detailed below.

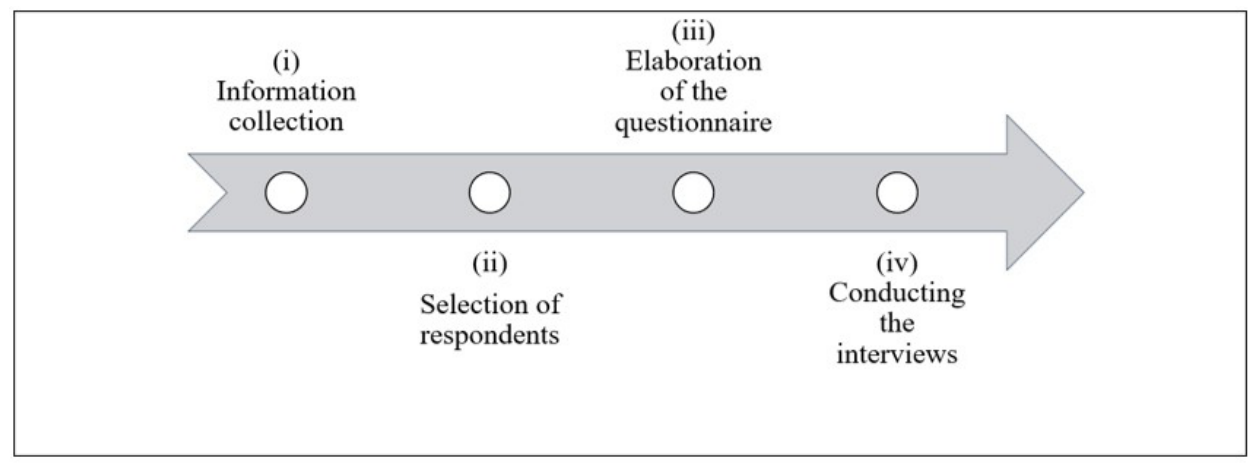

Figure 1. Planning for conducting the interviews.

(i) Collection of information on the topic: we used the technical reports and scientific published articles on websites of government agencies at national and state levels, in regulatory agencies such as the I National Agency of Petroleum, Natural Gas and Biofuels, among others and sector associations. This preliminary research allowed us to map different stakeholders engaged in the theme and a list of potential interviewees;

(ii) Selection of respondents: the interviewees selection was carried out to cover the most important value chain segments and assure information diversification. This process was crucial to ensure that the research could collect further evidence and explore each industry segment; 
(iii) Elaboration of the questionnaire: we prepared a reference questionnaire to guide the interviews and address specific aspects. This questionnaire served as a basis for the interviews, with possible adaptations to the questions depending on the interviewee's profile. Eventually, these adaptations unfolded into other topics pointed out by the interviewees themselves during the conversation. According to (Lune \& Berg, 2017), the flexibility of the semistructured interview allows comparisons across interviews and to pursue areas and information spontaneously initiated by the interviewee. This approach results in a more textured set of accounts from participants than that resulting from only scheduled questions. Table 1 shows the topic guide with a list of open-ended questions relating;

Table 1. Topic guide with open-ended questions.

\begin{tabular}{l}
\hline Questionnaire \\
\hline 1. Brief presentation of the institution you represent \\
2. Currently, how do you evaluate energy production from biomass and biogas in the country from the perspectives of the institution you \\
represent? \\
3. How do you look at the evolution to overcome the challenges in terms of the short (up to 2 years), medium (up to 5 years) and long (over 5 \\
years) horizon? \\
4. Explore the aspects: \\
- economic barriers (general in the country and specifically to the segment, including investor interest), \\
- technical (technological advances), \\
- political and regulatory (changes in progress or planned), \\
- environmental (Renovabio, project licensing, other incentives for using clean energy sources), \\
- logistics (challenges for transporting biomass), \\
- marketing (energy market conditions, biomass supply). \\
5. lndicate recommendations for solving the problems mentioned in the previous item (item 4).
\end{tabular}

(iv) Conducting the interviews: the interviews were conducted in São Paulo city between August 2019 and October 2020. The interviews were carried out in 15 institutions, including 19 people (Table 2). Each interview lasted between 60 minutes and 80 minutes, which were conducted both in-person and remotely, with the preference for face-to-face interviews. Some interviewees were in other cities, such as Rio de Janeiro, Brasília and Curitiba, in the remote mode. For the good use of information, all interviews were recorded.

Table 2. Overview of interviews conducted.

\begin{tabular}{|c|c|c|c|c|}
\hline Reference code & Occupation & No. of Interviews & Topic covered & Interview date \\
\hline A & President & 1 & Biogas experience & 30.08 .2019 \\
\hline $\mathrm{B}$ & Technical director & 1 & Trading energy & 19.09.2019 \\
\hline $\mathrm{C}$ & Manager & 1 & Investment and financing for the bioenergy sector & 12.12 .2019 \\
\hline $\mathrm{D}$ & President & 1 & Experience with the sector; RenovaBio policy & 18.11.2019 \\
\hline $\mathrm{E} / \mathrm{F}$ & Director of New Business & 2 & $\begin{array}{l}\text { Experience in projects for the sector; Natural Gas market; } \\
\text { RenovaBio policy }\end{array}$ & 09.03.2020 \\
\hline $\mathrm{G}$ & $\begin{array}{l}\text { Agricultural Production } \\
\text { Coordinator }\end{array}$ & 2 & Biomass production potential in Brazil & 30.08.2019 \\
\hline $\mathrm{H}$ & President & 1 & $\begin{array}{l}\text { Biogas/ biomethane alternatives; general characteristics of } \\
\text { the sugar-energy sector }\end{array}$ & 09.09.2019 \\
\hline $1 / \mathrm{J} / \mathrm{L}$ & $\begin{array}{l}\text { Superintendent } \\
\text {-Derivatives and Biofuels } \\
\text { Technical Consultant }\end{array}$ & 3 & $\begin{array}{l}\text { Sectorial planning and development integration with } \\
\text { other sectors; alternatives for biogas/biomethane; general } \\
\text { characteristics of the sugar-energy sector; RenovaBio policy }\end{array}$ & 20.02.2020 \\
\hline M & Professor & 1 & $\begin{array}{l}\text { Conditions of the sugar-energy sector; integration with } \\
\text { other sectors; environmental impact of wastes }\end{array}$ & 16.09.2019 \\
\hline $\mathrm{N}$ & Director & 1 & $\begin{array}{l}\text { Challenges of the sugar-energy sector; technical and } \\
\text { regulatory issues in the Natural Gas market }\end{array}$ & 12.06.2019 \\
\hline 0 & Director & 1 & $\begin{array}{l}\text { Straw destination possibilities; environmental impacts of } \\
\text { wastes from the sugarcane sector }\end{array}$ & 13.12.2019 \\
\hline $\mathrm{P}$ & CEO & 1 & Biomass recovery alternatives & 18.10.2020 \\
\hline Q & Bioelectricity Manager & 1 & General sector sugar-energy sector conditions & 28.08.2019 \\
\hline $\mathrm{R}$ & $\begin{array}{l}\text { Technological Prospecting } \\
\text { and Intellectual Property } \\
\text { Manager }\end{array}$ & 1 & $\begin{array}{l}\text { Pilot projects under development; interaction with other } \\
\text { agents and sectors }\end{array}$ & 28.10.2019 \\
\hline $\mathrm{S}$ & $\begin{array}{l}\text { Oil, Gas and Biofuels } \\
\text { Coordinator }\end{array}$ & 1 & $\begin{array}{l}\text { Current scenario; interaction with agents and other } \\
\text { government entities; development of public policies in the } \\
\text { area }\end{array}$ & 14.01.2020 \\
\hline
\end{tabular}


Although the answers derived from the pre-programmed questions, other questions were elaborated and deepened during the conversations, based on the researchers' perception of the interviewee's knowledge of a particular topic. Considering the sensitivity of some data and opinions presented by the consulted specialists, the interviews were conducted under confidentiality. For this reason, the audios or copies of the transcribed information were not included herein. In the text, information and opinions are presented without identifying the name of those responsible. The main topics addressed, the specific questions for each interviewee, and the coded form are shown in Table 2.

\subsection{Data analysis}

The interview transcripts were analysed using the framework approach described by (Pope \& Ziebland, 2017). The information was consolidated into patterns, trends and derived from five macro-categories of analysis. These macro-categories were established using a process called constant comparison, in which each item is checked and compared with the rest of the data to establish coherent analytical categories. After that, the researchers' team reviewed these five macro-categories, systematised them, and organised them into the concluding five categories presented in the results (section 3).

Aiming to associate the qualitative results with the quantitative results, we measured the percentage of responses from interviewees about a specific theme $(n=36$, being the total number of obtained answers and aggregated in analytical structure). Table 3 presents these percentages (Section. 3 - Results).

\subsection{Research limitation}

One limitation is that conducting interviews with specialists from different areas can be considered a methodological limitation in the research, as it opens up the possibility of responses with a comprehensive approach without bringing convergences. On the other hand, this broadening of the spectrum of themes treated shows complementary points of view and constitutes a picture expected to be richer over the sectors considered.

Another limitation is that we decided to interview specialists with a broad view of the sector. This approach can also be considered a limitation, as it included few direct representatives of the industry itself. Also, some of these specialists are dedicated to specific topics within the spectrum considered.

Finally, the option to aggregate the responses of the interviews, maintaining the confidentiality of the interviewees, may represent a limitation to the research. Conversely, this initiative has made it possible for specialists not to be afraid to address aspects or opinions potentially seen as inadequate in their positions.

\section{Results}

Table 3 summarises the barriers identified to disseminating electricity generation from biogas and biomass in Brazil. We divided the identified barriers into five categories: economic, circumstantial, cultural, technical, and other uses of biogas and biomethane. It is important to mention that some respondents reported the barriers to the uses of biogas and biomethane during the interviews, but they were not mentioned in the text since the study firstly aimed to focus on electricity generation barriers. Therefore, these barriers related to the uses of biogas and biomethane are not included in the quantification that we used to develop the representative graphics.

Table 3. Identified barriers.

\begin{tabular}{|c|c|c|c|c|c|}
\hline Item & Categories of barriers & Barriers & Interviewee & $\begin{array}{l}\text { Frequency of } \\
\text { theme addressed }\end{array}$ & Percentage \\
\hline \multirow{7}{*}{3.1} & \multirow{7}{*}{ Economic } & Biomethane as a diesel substitute & $\mathrm{H}, \mathrm{H}, \mathrm{l}, \mathrm{J}$ & 4 & $11 \%$ \\
\hline & & Economic and financial conditions of the plants & - & - & - \\
\hline & & Exchange rate & - & - & - \\
\hline & & $\begin{array}{l}\text { Biomethane versus natural gas: complementarity or } \\
\text { predatory competition? }\end{array}$ & $\mathrm{H}, 1$ & 2 & $6 \%$ \\
\hline & & $\begin{array}{l}\text { Challenge of expanding energy production by burning } \\
\text { straw }\end{array}$ & $\mathrm{L}, 1,0$ & 3 & $8 \%$ \\
\hline & & Needs for scale gain & $\mathrm{H}$ & 1 & $3 \%$ \\
\hline & & High investment costs & C & 1 & $3 \%$ \\
\hline
\end{tabular}


Table 3. Continued...

\begin{tabular}{|c|c|c|c|c|c|}
\hline Item & Categories of barriers & Barriers & Interviewee & $\begin{array}{l}\text { Frequency of } \\
\text { theme addressed }\end{array}$ & Percentage \\
\hline \multirow{9}{*}{3.2} & \multirow{9}{*}{ Circumstantial } & & & Total & $31 \%$ \\
\hline & & $\begin{array}{l}\text { Electricity sector rules and procedures that discourage } \\
\text { generation expansion }\end{array}$ & $\mathrm{D}$ & 1 & $3 \%$ \\
\hline & & Energy contracting rules & L, A & 2 & $6 \%$ \\
\hline & & Valuation of the attributes of energy sources & $\mathrm{P}, \mathrm{B}$ & 2 & $6 \%$ \\
\hline & & Regulated power market versus free power market & - & - & - \\
\hline & & The efficiency of biomass plants & - & - & - \\
\hline & & Generation Scaling Factor (GFS) crisis & Q & 1 & $3 \%$ \\
\hline & & Contract expiration and lack of perspective & - & - & - \\
\hline & & & & Total & $17 \%$ \\
\hline \multirow{4}{*}{3.3} & \multirow{4}{*}{ Cultural } & Challenge of traditions & $\mathrm{H}, \mathrm{G}, \mathrm{H}, \mathrm{Q}, \mathrm{H}, \mathrm{G}$. & 6 & $17 \%$ \\
\hline & & Exposure of agents to risks in the electricity sector & $\mathrm{N}$ & 1 & $3 \%$ \\
\hline & & A negative image of biogas: lack of quality projects & A & 1 & $3 \%$ \\
\hline & & $\begin{array}{l}\text { Lack of integration of the different sectors potentially } \\
\text { participating in the biogas chain }\end{array}$ & $0, \mathrm{M}$ & 2 & $6 \%$ \\
\hline \multirow{9}{*}{3.4} & \multirow{9}{*}{ Technical } & & & Total & $28 \%$ \\
\hline & & Availability and quality of raw materials & A & 1 & $3 \%$ \\
\hline & & $\begin{array}{l}\text { Regulatory requirements and difficulty in dealing with } \\
\text { them }\end{array}$ & $R, R$ & 2 & $6 \%$ \\
\hline & & Lack of technical training in general & $A, R$ & 2 & $6 \%$ \\
\hline & & Difficulties in maintaining of imported equipment & $\mathrm{R}$ & 1 & $3 \%$ \\
\hline & & $\begin{array}{l}\text { Specific to the use of straw: agronomic benefits of } \\
\text { using straw }\end{array}$ & - & - & - \\
\hline & & Specific to the use of straw: competition with $2 \mathrm{G}$ ethanol & 0,0 & 2 & $6 \%$ \\
\hline & & Specific to the use of straw: boiler corrosion & 0 & 1 & $3 \%$ \\
\hline & & & & Total & $25 \%$ \\
\hline \multirow{5}{*}{3.5} & \multirow{5}{*}{$\begin{array}{l}\text { Other uses of biogas } \\
\text { and biomethane }\end{array}$} & Lack of market for biomethane & - & - & - \\
\hline & & Logistics to supply the vehicle fleet & - & - & - \\
\hline & & Conversion of diesel engines to Otto cycle & - & - & - \\
\hline & & Difficulty in transporting wastes & - & - & - \\
\hline & & Doubts about the free market for natural gas & - & - & - \\
\hline
\end{tabular}

Each identified barriers are described in detail in sessions $3.1 ; 3.2 ; 3.3 ; 3.4 ; 3.5$. Figure 2 presents these barriers based on an importance gradient by colour. The darker shades were the most mentioned barriers, and the lighter colours represent those barriers less by the respondents.

\begin{tabular}{|c|c|c|c|c|}
\hline Economic & Circumstantial & Cultural & Technical & $\begin{array}{l}\text { Other uses of } \\
\text { biogas and } \\
\text { biomethane }\end{array}$ \\
\hline $\begin{array}{l}\text { Biomethane as a diesel } \\
\text { substitute }\end{array}$ & Energy contracting rules & Challenge of traditions & $\begin{array}{l}\text { Regulatory requirements } \\
\text { and difficulty in dealing } \\
\text { with them }\end{array}$ & $\begin{array}{l}\text { Lack of market for } \\
\text { biomethane }\end{array}$ \\
\hline $\begin{array}{l}\text { Challenge of expanding } \\
\text { energy production by } \\
\text { burning straw }\end{array}$ & $\begin{array}{l}\text { Valuation of the attributes } \\
\text { of energy sources }\end{array}$ & $\begin{array}{l}\text { Exposure of agents to risks in the } \\
\text { electricity sector }\end{array}$ & $\begin{array}{l}\text { Lack of technical training in } \\
\text { general }\end{array}$ & $\begin{array}{l}\text { Logistics to supply } \\
\text { the vehicle fleet }\end{array}$ \\
\hline $\begin{array}{l}\text { Biomethane versus natural } \\
\text { gas: complementarity or } \\
\text { predatory competition? }\end{array}$ & $\begin{array}{l}\text { Electricity sector rules and } \\
\text { procedures that discourage } \\
\text { generation expansion }\end{array}$ & $\begin{array}{l}\text { A negative image of biogas: lack of } \\
\text { quality projects }\end{array}$ & $\begin{array}{l}\text { Specific to the use of straw: } \\
\text { competition with } 2 \mathrm{G} \\
\text { ethanol }\end{array}$ & $\begin{array}{l}\text { Conversion of } \\
\text { diesel engines to } \\
\text { Otto cycle }\end{array}$ \\
\hline Needs for scale gain & $\begin{array}{l}\text { Generation Scaling Factor } \\
\text { (GFS) crisis }\end{array}$ & $\begin{array}{l}\text { Lack of integration of the different } \\
\text { sectors potentially participating in } \\
\text { the biogas chain }\end{array}$ & $\begin{array}{l}\text { Availability and quality of } \\
\text { raw materials }\end{array}$ & $\begin{array}{l}\text { Difficulty in } \\
\text { transporting wastes }\end{array}$ \\
\hline High investment costs & $\begin{array}{l}\text { Regulated power market } \\
\text { versus free power market }\end{array}$ & & $\begin{array}{l}\text { Difficulties in maintaining } \\
\text { of imported equipment }\end{array}$ & $\begin{array}{l}\text { Doubts about the } \\
\text { free market for } \\
\text { natural gas }\end{array}$ \\
\hline $\begin{array}{l}\text { Economic and financial } \\
\text { conditions of the plants }\end{array}$ & $\begin{array}{l}\text { The efficiency of biomass } \\
\text { plants }\end{array}$ & & $\begin{array}{l}\text { Specific to the use of straw: } \\
\text { boiler corrosion }\end{array}$ & \\
\hline Exchange rate & $\begin{array}{l}\text { Contract expiration and } \\
\text { lack of perspective }\end{array}$ & & $\begin{array}{l}\text { Specific to the use of straw: } \\
\text { agronomic benefits of using } \\
\text { straw }\end{array}$ & \\
\hline
\end{tabular}

Figure 2. Barriers identified by importance gradient. 
We divided respondents into ten macro-categories and quantified the barriers cited by each group of respondents, as shown in Figure 3.

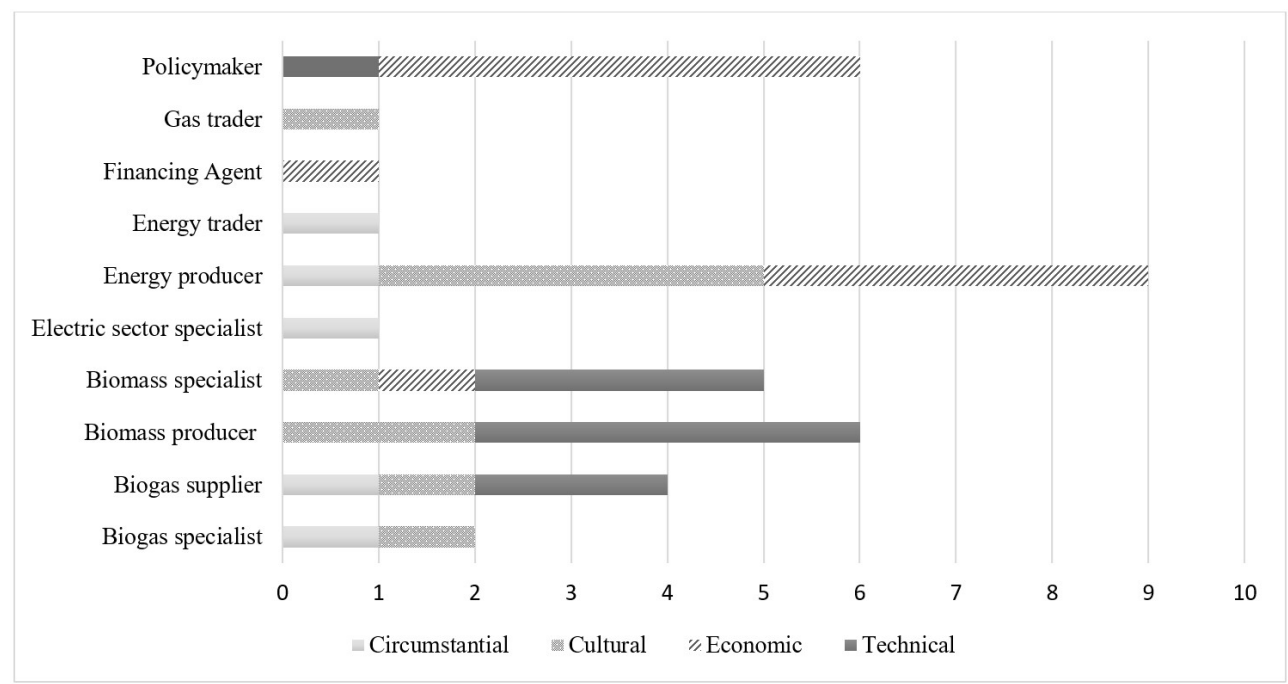

Figure 3. Cited barriers by macro-categories of respondents.

\subsection{Economic barriers}

The economic barriers that most impact the development of electricity from sugarcane biomass or biogas discussed by the interviewees are detailed below in Subsection 3.1.1; 3.1.2; 3.1.3; 3.1.4; 3.1.5; 3.1.6; 3.1.7. Some of the respondents' statements are highlighted throughout the text.

\subsubsection{Biomethane as a diesel substitute}

According to the interviewees, the alternative of replacing the diesel fleet seems promising in terms of diesel savings and reduction of greenhouse gas emissions. However, it represents a barrier to expanding the generation of electric power in the plants from biogas. Despite this perception, some respondents also pointed out the heterogeneity of the plants. They highlighted the plants' low likelihood of adopting a single route. One of the respondents estimated that the sugar-energy sector has an annual diesel expenditure of R \$ 7 billion to R \$ 10 billion per year. This projection considers the use of, on average, 4 litres of fuel per ton of processed cane and the processing of around 650 million tons per year across the country. Therefore, any reduction in diesel expenditures represents an operating capital gain for the plants for the interviewee.

Given these values and the fact that plants must periodically renew their fleets of trucks and tractors regardless of market conditions, most of the experts consulted in this research understand that biogas production to replace diesel is the most likely route for plants to develop projects in the area. About this subject, an expert said:

The remuneration for the replacement of diesel with biomethane is much better than the power generation (Interviewee $\mathrm{H}$ ).

In the interviewee's opinion, the great characteristic of this energy source is that it is a distributed source. The specialist argued that Brazil is a continental country and spends fuel transporting liquid fuel from the coast to the interior. According to him, this raw material (waste) could make the fuel available in the country's interior.

Many litres of diesel is often burned by transportation to deliver one litre of diesel in some regions of the country (Interviewee H).

Another specialist added that it is difficult to find another application that yields better when replacing the diesel fleet with biomethane. According to him, as long as there is an opportunity to use biomethane for transport, electricity will not be economically viable.

Considering the energy contained in the molecule costs more than the energy of the electron, it makes even more sense to use of diesel in fleets in the sugar-energy sector (Interviewee J). 
Despite the general perception that the most likely route for biogas produced by the plants is replacing diesel from the plants' fleets, some respondents pointed out the heterogeneity of the plants and the low probability of adopting a sing route.

The sector has 367 plants: it is difficult for you to say what the route will be. (...) What technology will dominate? I do not know. It will greatly on each project (Interviewee J).

In the expert's opinion, if the technological advance is very expressive as expected, it will be very tempting to create independence in the plants' fleets. However, he emphasises that there is no way to say if the sector will follow a single route.

\subsubsection{Economic and financial conditions of the plants}

Heterogeneity is also brought about concerning the economic and financial situation as a limiter to investments for some plants.

One of the respondents assessed that the sector has priority group, capitalised, and suitable investment needs. This group account for approximately $40 \%$ of the grinding capacity. The rest of the plants, about half of the units, could make new investments possible only through partnerships. Other experts pointed out that the companies would be in critical condition, many in judicial recovery, thus unable to invest or to attract new partners to develop projects. In experts' opinion, this situation has worsened in recent years due to the high indebtedness of the plants due to the investments contracted in the 2000s and the control of fuel prices practised by the Dilma Roussef government.

\subsubsection{Exchange rate}

From the interviewees' point of view, the currency devaluation triggered at the beginning of 2020 by the global coronavirus crisis represents a threat to the development of the projects. This devaluation is because most of the equipment is imported. The matter was only addressed in an interview conducted in early March, most likely because the currency has maintained a relatively stable behaviour in recent years (with more significant variations only in times of market tension, such as elections).

\subsubsection{Biomethane versus natural gas: complementarity or predatory competition?}

For the experts consulted, the development of hybrid plants - in which biomethane or natural gas are used as complementary alternatives to cogeneration with sugarcane bagasse - can integrate these units into the distribution network for piped natural gas, making room for the companies to operate all year round. This integration is also an alternative for plants that want to send biomethane to consumers by the free market for natural gas or by supplying to a regional distributor.

However, one of the interviewees argues that he always wins the best price in the free gas market. As a justification for the barrier, one of the interviewees mentioned that, in the United States, the development of biomethane projects was only possible in regions far from the natural gas transportation networks. A respondent said:

I can't see biomethane competing with gas. Where there is natural gas, biomethane is not enough. Supposedly, it arrives only under particular conditions. (Interviewee $\mathrm{H}$ ).

Given the barrier, it would be more interesting for plants close to the natural gas network to develop a strategy aimed at other uses of biogas in their operations, said another respondent:

If it is a plant that has natural gas in your region, this aspect of serving the local market tends to be less favourable (...). This restriction will be remedied with some mechanism that reduces this disadvantage, encourages this product, and considers replacing diesel (Interviewee 1).

Another expert raised the low penetration of natural gas transportation networks, even in the state of São Paulo State, one of Brazil's largest natural gas markets (for non-thermoelectric use). The state has the most significant natural number of customers, also the largest extension of the natural gas network in the country, with 19,629 km (Dutra \& Rodrigues, 2019). This condition makes it difficult to inject biomethane into the distribution network and dispose of natural gas to power plants. 


\subsubsection{Challenge of expanding energy production by burning straw}

Respondents pointed out that burning sugarcane straw in the boilers or biodigesting it are alternatives to increase electric power production in the plants via cogeneration or via biogas in a motor-generator. Yet, in addition to the technical aspect (discussed in Technical Barriers), straw has the aggravating factor that, to be used, it needs to be collected from the field, and the straw collection has a cost that needs to be considered. About this, a respondent said:

Bagasse has zero cost. It even has an opportunity cost because it can be sold, but it costs nothing to the plant because it is waste that the plant has to produce anyway. (Interviewee $\mathrm{L}$ ).

The respondent added that the sale price of energy could not have a premium for the extraordinary expense of transporting the raw material:

Electricity, when sold by the plant, makes no distinction as to whether it is straw or bagasse (Interviewee 1).

Consulted agents also warned about the difference in alternatives for electricity production from bagasse and straw, with biogas, since its commercial use is still relatively distant from the market. In this context, some experts said the cost of producing biogas could also impact the sale price of energy, making it less competitive.

You are comparing a consolidated alternative (...) from a regulatory point of view there is a problem, but this problem will exist for any modality, whereas biogas has yet to open the way for viability (Interviewee 0).

\subsubsection{Needs for scale gain}

Several respondents replied that some projects are currently being implemented, but the sector is still waiting to make new investment decisions that will effectively give it scale. The subject is also discussed in the chapter cultural barriers. One of the respondents said:

We have to actually have a dozen plants operating in Brazil to spread the technology (Interviewee H).

\subsubsection{High investment costs}

The interviewees highlighted the high investment cost of the equipment, especially those costs for implementing imported biodigestion systems for municipal solid waste and sewage.

Perhaps something that we need to stimulate in the chain is national technology development. Today, everything is imported (Interviewee C).

\subsection{Circumstantial barriers}

The interviews pointed out the challenges of dealing with the changes undergone by the Brazilian electricity matrix is going through concerning the competitiveness of sources. According to the interviewees, the advancement of wind and solar sources and the possibility of extracting natural gas more competitively than the pre-salt caused two historically important sources to be "a little low": hydroelectric and bioelectricity. The themes identified as Circumstantial barriers and the challenges to deal with them are described below from the interview results (Subsection 3.2.1; 3.2.2; 3.2.3; 3.2.4; 3.2.5; 3.2.6; 3.2.7).

\subsubsection{Electricity sector rules and procedures discourage generation expansion}

During the interviews, experts point out the need for the country to choose the most competitive sources due to the difference in prices charged concerning other sources of energy generation, for example, solar and wind energy. 
Why am I going to spend buy $R \$ 250$ on an electron that I can buy for $R$ \$ 100 from another supplier? To benefit a source? (Interviewee D).

\subsubsection{Energy contracting rules}

Another difficulty described by interviewees about biomass projects is the rules of the auctions themselves. According to experts, if the source faces competitiveness difficulties with wind and solar, the challenge could be even more significant in the competition with coal or natural gas projects, with which it has been competing in the last auctions. For experts, the way auctions are organised is questionable since the cost structure of these projects is very different. For instance, the plant scale is disproportionate. It is means $50 \mathrm{MW}$ in biomass plants and more than $1000 \mathrm{MW}$ in gas plants.

On the other hand, the respondents also warned that, while coal and gas thermal plants have the expense with the purchase of fuels in their cost composition, bagasse is an industrial waste, at no cost to the generator. One of the experts said:

Could it be that the other sources are suffering from this? Because coal and gas have to be paid for, "bagasse is free" (Interviewee $\mathrm{L}$ ).

In the case of biogas, the reasoning is the same, completed another specialist. He argued that the raw material is zero cost and that the biodigestion process consumes an organic material in that environment and is not used in the field.

The significant point is that the raw material is zero cost. Do you agree? The straw, the pie and the vinasse are there (Interviewee A).

\subsubsection{Valuation of the attributes of energy sources}

Most respondents reported that biomass entrepreneurs resent the source attributes not being considered in the country's energy policy. They argue that the prices and other current conditions of energy auctions would not recognise the sources' attributes. In the case of biomass, the positive aspects of the source disregarded would be the following: i. the energy generated from sugarcane bagasse is renewable, with zero emissions of greenhouse gases; ii. biomass does not require subsidies and exemptions made available to other sources, such as wind and solar.

The interviewees highlighted the need to make regional auctions feasible for contemplating these attributes to hold regional energy auctions. In addition, they remarked on the importance of introducing the hourly price, scheduled for 2020, which stands out mainly in the energy produced by biogas engines. One of the experts pointed out that hourly price is viable because biogas is the only renewable source that is not intermittent - it is possible to store both biomass and biogas to generate at times of higher prices, without depending on the sun, rain or wind quick activation. In this context, the interviewee said:

More than a barrier, it is an opportunity (Interviewee P).

Another specialist completed:

Biogas is the only dispatchable renewable source. For this reason, the hourly Daily Settlement Price (DSP) will add much value to biogas (Interviewee B).

\subsubsection{Regulated power market versus free power market}

According to those interviewed, the regulated power market auctions still represent an important entry point for new plants. One of the respondents' highlights is the lack of isonomy between projects connected to the grid for energy export projects from different energy contracting environments. Several specialists also claim that projects aimed at the regulated market prefer access to the grid. In specialists' opinion, the strategy of some generators to enable the implementation of new plants includes participation in the regulated power market auction and negotiating energy at relatively low prices to allow the connection of projects. Another factor pointed out is that the preference of the plants for the regulated power market could reduce or eliminate the risk of exposure to the short-term market. 


\subsubsection{Efficiency of biomass plants}

In the expert's opinion, the low efficiency of biomass plants represents a barrier to the expansion of energy generation, as the results of the projects discourage the realisation of new investments. According to interviewees, this situation conversely indicates room for improvement in the sector's competitiveness through new investments. One of these respondents points out it is essential to follow the examples from wind farms, which has been developing projects with the increase in towers and the power of wind turbines and the efficiency of photovoltaic panels.

\subsubsection{Generation Scaling Factor (GSF) crisis}

One of the greatest problems that afflicted the Brazilian electricity sector was the hydrological risk crisis or the GSF (Generation Scaling Factor) crisis. Briefly, the GSF refers to the ratio between the energy generated by hydropower plants and its physical guarantee. An adjustment factor above 1 indicates a production greater than the physical guarantee, while a GSF below 1 indicates a lower production. In 2013, a low GSF was systematically verified due to the low hydropower generation (numerator) and an incompatible (higher) physical guarantee with the effective generation potential of the plants. The first phenomenon may result from hydrology or changes in operating policy, while the second results from the attribution of physical guarantee to the plants by the Brazilian granting authority (Sales \& Hochstetler, 2018).

This scenario led to the exposure of hydraulic generating agents in the short-term market (MCP), where energy contracts are accounted for since they could not deliver all of the energy traded.

As the causes of the problem are unrelated to their operating conditions, these generators obtained court injunctions not to pay for the energy they could not deliver. This situation harmed those generators that provided volumes of power above their physical guarantee and was not paid in the MCP accounting (Sales \& Hochstetler, 2018).

Thus, the GSF crisis was also pointed out as a barrier to expanding electricity from biomass. One of the interviewees recalled that surpluses produced by biomass plants above their physical guarantee must be assigned to settlement in the short-term market. The problem is that such payments are stalled because part of the agents have injunctions to avoid covering costs related to the GSF (generation scaling factor). As a result, in the middle of last year, biomass plants would have more than $\mathrm{R} \$ 500$ million to receive in the market, discouraging them from generating above their physical guarantee or investing in expansion.

In the view of a consulted specialist, there would be ill will by the government to resolve these difficulties in the biomass sector. This behaviour could be associated with the lack of support to the sector by the government at the beginning of the past decade. An interviewee said:

In 2010-2011, the government was desperate for energy. (...) Some large mills were not partners (Interviewee Q).

Currently, the crisis has been practically resolved considering the compensation of the losses of hydraulic generators in the process with the expansion of grants for their plants, which enabled the withdrawal of most lawsuits in court and payment of outstanding amounts (Câmara de Comercialização de Energia Elétrica, 2021b).

\subsubsection{Contract expiration and lack of perspective}

Experts reported concerns about the future of energy from biomass due to fears of sector agents' expiration of contracts for significant volumes of energy from these plants. The scenario described is that by 2024, almost $50 \%$ of the contracts in the regulated power market are expected to expire, for a total of 823 average MW. Most plants with expiring contracts must invest significantly in maintenance/refurbishment to continue serving the National Interconnected System (NIS). In the respondents' opinion, the renegotiation of these contractors requires clarity about what the electricity sector's institutional environment will look like now and not after 2024.

\subsection{Cultural barriers}

Why should someone modify a business that has been making a profit for 500 years? (Interviewee $\mathrm{H}$ ).

The question is from one of the experts heard in this research. It refers mainly to the resistance of sugarenergy plants to invest in biogas production from vinasse and filter cake, but it can also be considered from 
other potential input producers. The fact is that there is a significant lack of knowledge about opportunities and their potential among potential producers, as discussed below in Subsection 3.3.1; 3.3.2; 3.3.3; 3.3.4.

\subsubsection{Challenge of traditions}

For the experts, the challenge to established traditions increases significantly if the changes also depend on significant investments and if there is still a great lack of knowledge regarding the possibilities they contemplate and their effects. The fact is that the lack of knowledge and lack of interest among potential producers of the technologies used for biogas production and the possibilities and advantages of biofuel are still among the main barriers to developing projects.

From the interviewee's point of view, this lack of knowledge can quickly turn into fear and refusal when presenting an opportunity to participate in an initiative of the type. One respondent cited this lack of information as the main difficulty for engaging agricultural producers in producing biogas from waste in past experiences. Note that, in this specific case, there would be no cost for producers since it was a project conducted by a company to improve the quality of reservoir water.

Another difficulty pointed out is that small and medium rural producers do not have access to biogas and electricity. Or else, even knowing some technologies, such agents would not measure the benefits behind them, which demand detailed empirical and economic analyses to justify the investments, even though these projects are small. An expert evaluated:

The generation of energy (or the production of biogas) is not the main activity of rural producers (...). There are those whos cannot find suppliers for setting up a project (Interviewee G).

In the interviewees' narratives, there are still few projects in place that contribute to these difficulties. Many producers only believe in the solution's viability if they verify its application in practice. According to the specialists, breaking this vicious cycle is a challenge since many small agricultural producers are unaware of the opportunities. This challenge represents a little demand or even lack of interest among development institutions. It is worth highlighting that these small producers cannot hire consultants to identify the possibilities of addressing technical challenges.

The conservative reasoning does not apply only to small and medium farmers. Although they have the knowledge, access to information or can hire consultants, large sugar cane mills would also be waiting for the results of the Cocal and Raizen projects to define their strategy about the theme. An interviewee said about this theme:

The mill owner, when he looks to the side and sees that a colleague did something and it worked, he is interested. (...) In the case of cogeneration, the process also started gradually (Interviewee $\mathrm{H}$ ).

Another interviewee completed:

The sector is expecting examples. (...). A successful project can stimulate new energy generation projects in the sector (Interviewee Q).

In evaluating specialists, the conservatism of the Brazilian agricultural sector also means that priority is given to expanding agricultural production in a surplus of investments resources and opting for little-known innovations. A specialist referred to sugar-energy plants in a reflection that can also be extended to other rural producers.

Investors in the wind and photovoltaic sector are much more active, developers, than those in the sugar-energy sector. (Interviewee H).

The diffusion of knowledge is seen as the best alternative to reverse this situation. An expert stated:

It is necessary to make projects visually simple to interpret how much I have, how much I will pay, how long and what the risks involved are. (Interviewee G).

\subsubsection{Exposure of agents to risks in the electricity sector}

According to respondents, the diversification of energy sources generated from waste can help reduce risks and costs in the Brazilian electricity sector. It increases the supply of input in regions of the country's interior 
without reinforcements in the country grids. However, at the same time, it increases the risks for agents who are not used to the challenges inherent in the electricity sector. After all, the activity is different from the daily life of the rural producer, who does not have the resources to manage energy.

None of them (plants) has a trader, sells the energy to CPLF (São Paulo Company of Power and Light) or a Matrix, Trader (...). It is a very conservative sector; it still has many family businesses (Interviewee N).

\subsubsection{Negative image of biogas: lack of quality projects}

Problems in the quality of biogas projects implemented since the 2000s would also help explain some agents' resistance to the sector, in the experts' opinion. These are projects aimed at flaring biogas from flare landfills to negotiate carbon credits, but without adequate technology, in the view of a specialist:

Everyone thinks it is easy to make biogas. But there it is with low efficiency in the processes, and the biodigester always stops working. This threatens the segment credibility (Interviewee A).

\subsubsection{Lack of integration of the different sectors potentially participating in the biogas chain}

According to the specialists consulted, the integration between agents from other sectors producing biogas from their residues is still relatively low. There is little exchange of information, for example, between the primary sanitation sector and the sugar-energy sector. In this sense, some specialists advocate the role of the public authorities favouring biogas precisely as an alternative to integrate the different job options since the projects can help solve problems with waste in general, including agricultural, sewage treatment plant waste and urban waste. About this issue, an expert said:

Biogas is a solution for this. (...) We have to make some production chains or municipalities that have this problem at hand to be aware that biogas is part of the solution (to these problems) (Interviewee 0).

Also, another expert said:

I think we have not yet disclosed or priced the environmental benefits of biogas. When I say the advantages, I am not just saying to replace fossil fuel, but solving the problem of waste and basic sanitation (Interviewee M).

\subsection{Technical barriers}

Some technical barriers identified are confused with economic and cultural barriers. In the first case, some challenges related to rule, the high cost of certain items, or the lack of access to such things because of their high price. In turn, cultural issues contribute to disregarding opportunities or overcoming technical challenges. The themes related to technical barriers are in Subsections 3.4 .1 ; 3.4.2; 3.4.3; 3.4.4; 3.4.5; 3.4.6; 3.4.7.

\subsubsection{Availability and quality of raw materials}

In the consulted expert's opinion, the biodigestion technologies are available and work properly. However, the success of the projects also depends on the stability of biomass production. For instance, stock availability is essential since the projects should operate without interrupting raw materials' amount or quality. In this sense, variations in the characteristics of the inputs (vinasse, filter cake and straw), risks of contamination, presence of soil and stones can hinder the process. Another issue is that, to avoid problems, it is necessary to work with temperature control and controlled feeding. Possibilities for solving problems include eventual pH correction. One of the interviewees cited the high potential for variation in composition; another worrying factor is the presence of antibiotic residues (in the case of vinasse). These residues can kill bacteria in the biodigester. These issues require patience and dedication from investors in the projects. About this theme, an expert joked:

It is necessary to bring the financial resources, the technological experience because, in the beginning, it will be a problem, the bacteria will go on strike, they will want to eat something else, they will go on a diet... (Interviewee A). 


\subsubsection{Regulatory requirements and difficulty in dealing with them}

The strictness of the regulatory requirements, particularly for biogas production in the sewage treatment plants, worries specialists in the area, as it can discourage project implementation. Among the problems identified is the lack of accredited laboratories for analysing siloxane emissions, other pollutants, and biomethane odorisers for small plants. The fear is that excessive rigour will end up limiting the development of technology.

One of the experts consulted pointed out the need to interact with a control and inspection body, such as the Environmental Company of the State of São Paulo and the National Agency of Petroleum, Natural Gas and Biofuels. It is necessary to promote a more structured discussion and revert questions about laboratory requirements, such as siloxane emissions. An expert said:

Because this is a requirement that agents tell for us here, but abroad, in Europe, this doesn't happen (Interviewee R).

The specialist consulted also highlighted the need for improvements regarding the purification of biogas:

We have many challenges in the purification area. (...) There are many things that we need to improve. In some cases, they are fine adjustments, other more grotesque adjustments. But there is room to move forward (Interviewee R).

\subsubsection{Lack of technical training in general}

The interviewees point to the lack of workforce training as a barrier, particularly in biogas production. In projects for using agricultural wastes, the challenge is to identify professionals to operate the plants.

Our barrier is much more in operation and maintenance, in the knowledge to develop arrangements and conduct projects (...). When I want trained people, who master the topic, it is complicated to find (Interviewee A).

Potential project developers also see the professional lack of training as an issue to biogas plants from sewage treatment. An expert said:

In addition to the teams' lack of knowledge, there are difficulties in disseminating knowledge to professionals... (Interviewee R).

\subsubsection{Difficulties in the maintenance of imported equipment}

The interviewed experts also treat the combination of imported equipment with low technical knowledge as a threat to the functioning of the projects. On this topic, one of the respondents said that any problem with the equipment requires specialised labour, often from abroad, as all equipment is imported.

If there is any problem with the equipment, how do we resolve since all technology comes from abroad? (Interviewee R).

\subsubsection{Specific to the use of straw: agronomic benefits of using straw}

According to experts, the straws left in the field protect the soil against erosion. Also, straws increase the water percentage in the ground and decrease the rate of water that runs off the surface. The straw has nutrients, and a part of them goes to the soil, improving the organic matter and reducing the need to use additives. Therefore, there is a discussion that it may be better for the plant to conserve straw in the field instead of assigning it to other purposes.

\subsubsection{Specific to the use of straw: competition with $2 \mathrm{G}$ ethanol}

Another issue concerns the use of the material to produce second-generation ethanol. An expert said that since starting to collect straw from the field, the discussion began as to which alternative would be the best between using straw for $2 \mathrm{G}$ (second generation) ethanol or using straw for electricity generation. On this subject, the expert questioned: 
What is better? Using a straw for $2 G$ or electricity generation? This will be an economic decision: the option that pays better will benefit (Interviewee 0).

The specialist added that even if the straw is used to produce $2 \mathrm{G}$ ethanol, there will still be the possibility of generating bioelectricity. However, the energy produced is lower if all the existing straw in the field is used. In any case, this arbitration will have to be considered by the plants, in his opinion.

It will not be as much as if you use all the straw to generate energy, but an additional part of electricity will be produced (Interviewee 0).

\subsubsection{Specific to the use of straw: boiler corrosion}

After harvesting, the straw availability in the field depends on several factors, such as the harvesting system used, the climate, and sugarcane variety.

Considering that sugarcane straw consists of three main components green leaves, dry leaves and tips (or tops), the most important differences among the straw components and bagasse (currently used in boilers) are the higher potassium and chlorine content in the straw, mainly in the tops, and the amount of calcium and magnesium. These substances could cause corrosion and slag in boilers. (Bizzo, 2017; Leal et al., 2013).

Experts consulted narrated that they thought that straw equalled bagasse at the beginning of the first attempts to use straw in boilers. However, problems began to arise as they started to use more straw, and the straw percentage in the boilers increased to around 10\%. First, the problems occurred in feeding because the density of the straw is lower than the bagasse since the straw has a coarser particle size.

The boiler and equipment are designed for bagasse, and there is a difference between the two materials, noted the expert. He also mentions that the contents of ash, chlorine, potassium and sulphur are higher in straw than in bagasse. In his opinion, the straw destination portion for biodigestion already represents an advantage since it can reduce the presence of the "green tip" of the straw in the boiler. In this case, the interviewee has referred to the tops of straw described above.

These elements are there in the straw and cause corrosion of the boilers (Interviewee 0).

\subsection{Specific barriers to other uses of biogas and biomethane}

This work aims to address barriers to the expansion of electricity generation from biomass or biogas. However, given the proximity of the themes, also the interviews identified barriers for biogas (and biomethane) alternative uses. As biogas production alone - even for different services - could be an indirect stimulus to electric power production, it is identified as a barrier that also hampers evolution in this sense, as described below in Subsections 3.5.1; 3.5.2; 3.5.3; 3.5.4; 3.5.5.

\subsubsection{Lack of market for biomethane}

According to some interviewees consulted, the lack of an established regional market, with industries, businesses, and potential households that consume biomethane, is associated with the lack of interest of sugarenergy plants to produce the fuel and sell it piped gas distribution network.

\subsubsection{Logistics to supply the vehicle fleet}

Experts highlighted that in projects that include diesel replacing with biomethane, the plants face a logistical problem. In other words, logistics could favour the supply of trucks that transport sugarcane or ethanol, which move close to the central production structures (of biomethane) at the plants. Yet, the supply of equipment such as tractors and harvesters would be more complicated since the fuel would have to be transported to the point of operation on extensive farms, often far from biomethane production. The power plants have to evaluate the alternatives such as gas compression, pipes installation, or gas liquefaction to transport, pointed out the specialist. 


\subsubsection{Conversion of diesel engines to Otto cycle}

The respondents stated that converting the engines of vehicles that currently use diesel into Otto-cycle engines to work with biomethane is still a technical challenge to implementing diesel replacement projects in the plant's fleets. In addition to converting equipment, there are tests on movements with New Holland tractors and Scania trucks.

\subsubsection{Difficulty in transporting wastes}

Some interviewees said that transportation is a barrier to generating biogas other than sludge production (or another kind of waste) since it is complex and expensive. Therefore, it may be more appropriate to generate energy locally in the case of sewage treatment plants.

\subsubsection{Doubts about the free market for natural gas}

The free market for natural gas, in which producers can contract directly with buyers, is already regulated in São Paulo, but no contract has been drawn upon those bases. According to respondents, the absence of the contract contributes to a lack of knowledge and insecurity for agents.

\section{Discussions}

The generation of electric energy from biogas still face numerous barriers. Sectorial aspects and business difficulties also challenge the expansion of cogeneration technology based on biomass, which has already consolidated in the sugar-energy sector.

The interviews carried out in this researcher showed that one of the main barriers to biogas is related to the dynamics of the sugar-energy sector itself. About 17\% of the quotes shown in this survey concern resistance to changing business models or breaking traditions.

In general, the barriers most cited by respondents were biomethane as a diesel substitute and the challenge of traditions. So that means cultural and economic barriers, as shown in Figure 2. Specifically, policymakers were the ones that most highlighted economic difficulties and the energy producer was the group that most reported issues related to culture change as a barrier to the expansion of electricity from biomass and biogas. Although, the cultural barriers were described by different macro-categories of interviewees, such as gas trader, energy producer, biomass specialist, biomass producer, biomass supplier, biogas specialist (Figure 3). These results corroborate Hughes et al. (2020), who described the lack of interest by producers as a barrier to energy expansion by the sugar-energy sector.

It is worth noting, as mentioned in section (3.2.2), that biogas technologies face competition from other renewable sources of electricity generation technologies such as solar and wind. In this sense, the interviewees pointed out the need to valuation the attributes of energy sources and reinforced the benefits of introducing the hourly price and auctions dedicated to biomass.

Making a parallel with other developing countries, researchers in India suggest that the market risks of biogas for electricity generators can reduce by supplying based on price (preferential tariffs) or based on quantity (minimum purchase) (Mittal et al., 2018).

The replacement of diesel used by the plants' fleets could represent the viable economic decision to use the biogas produced from the vinasse and filter cake, limiting the amount used to generate electricity. The diesel replacement appeared in $11 \%$ of the interviewees' citations.

Financial difficulties of the plants, sector conservatism, issues in the electricity sector, and lack of knowledge also accentuate the challenge, limiting the potential and interest in developing new projects. These aspects were also highlighted by Mathias \& Mathias (2015), who described the needs of governmental agenda focused on legal, political, and regulatory challenges.

Besides the economic benefit, the electricity production from biogas and biomass tends to be stimulated by different aspects, such as introducing hourly prices, the separation of ballast and energy, the development of RenovaBio. The experts also defend implementing a stimulating and long-term sectorial policy, with clear and continuous guidelines, including efforts towards a regular and growing contracting of bioelectricity and biogas in regulated auctions. Ferraresi \& Calia (2019) also pointed out the need for price predictability in the free contracting environment and specific policies accounting for biomass's social and environmental externalities. The Union of the Sugarcane Agroindustry of the State of São Paulo also advocates that auctions have to be 
promoted in the regulated environment for biomass, with pricing models that incorporate the externalities of bioelectricity and the characteristics of each project (e.g. retrofit; greenfield; use of straw and bagasse; generation of biogas) (União da Indústria de Cana-de-Açúcar, 2020).

Limiting the disposal of untreated vinasse in the field should also serve as a stimulus, as it will require the search for a solution to reduce the environmental impact of the waste.

Evidently, in this critical moment that started in March 2020, any challenge is compromised by the broader crisis caused by the coronavirus pandemic, whose outlines are still undefined and go well beyond the exchange rate issue (worrying, since projects depend on imported equipment) pointed out in this work.

After the critical hiatus, the problems pointed out here will remain on the agenda so that it is possible to make greater use and more efficiently use of the potential for power generation from biomass and biogas in the country.

We evaluated efforts at a medium or high level to overcome the barriers identified in this study since the strategies imply changes in the rules of the electric sector or even integration of different segments. Besides, the economic and political moment that the country is experiencing must be considered, which can hinder any change in rules.

Nevertheless, the incentive to use biogas to generate electric power by the plants opens several opportunities for job creation; for example, overcoming identified barriers is essential in the current context.

\section{Conclusions}

Identifying the main barriers is of significant importance for scaling up bioenergy production. This paper draws a scenario of the main barriers in the Brazilian context from the sector experts. Our study contributes by identifying five barrier categories, and among these categories, financial and cultural barriers stood out.

Financial difficulties of the plants, sector conservatism, issues in the electricity sector, and lack of knowledge contribute to accentuating the challenge, limiting the potential and interest in developing new projects. The interviews also exposed that electricity production from biogas and biomass tends to be stimulated by introducing hourly prices and the attributes source valorisation. The electricity sector specialists advocate the valuation of the sources' attributes as an alternative so that the planning effectively contemplates the sources with the best cost/benefit ratio. These and other findings from this study can be used by governments, market agents and researchers interested in the theme as it provides non-explicit information and reveals broad perspectives for integrating the themes of biogas and biomass. Following stand out: a) need for professional training to operate biogas plants, work directly with equipment, often imported, which requires specialised labour; b) need for regional biogas market development, with industries, businesses, and potential households that consume biomethane; c) need for the development of logistics for different types of biomass; d) need to disseminate knowledge about projects, benefits, feasibility and potentialities of using biomass to generate electricity for different scale of biomass generators.

There are policy implications of this study. The main barrier category, economics, can be overpass through specific policies mechanisms. Government financial support plays an essential role in bridging "[...] the viability gap and making biogas projects economically viable [...]" (Mittal et al., 2018, p. 369). Policy lessons and successful mechanisms from other countries can help, such as investment grants for the production and sale of biogas, biogas market incentive programs, and fiscal incentives (energy tax and carbon tax) (Banja et al., 2019).

The paper also contributes to identifying aspects of improvements in existing policies such as electricity sector rules, energy contracting rules or lack of integration lack of the different sectors that could enhance the biogas chain. Based on our research, policy recommendations can be drawn for overcoming the identified barriers.

For future research, we suggested developing a comparative framework on lessons learned from the experience of countries such as Germany and Sweden, which advanced in the power generation from biomass or biogas, overcoming similar barriers.

\section{Acknowledgements}

We thank the National Energy Agency (ANEEL) for the support grant awarded through the Annual for Research and Development Program based on the technical-scientific cooperation agreement between CESP (Energy Company of the State of São Paulo) and FUNEP (Paulista State University Research Support Foundation - grant agreement number: ANEEL: 00061 - 0057/2017. 


\section{References}

Agência Nacional do Petróleo, Gás Natural e Biocombustíveis - ANP. (2020). RenovaBio. Retrieved in 2020, March 20, from http://www. anp.gov.br/producao-de-biocombustiveis/renovabiohttp://www.anp.gov.br/producao-de-biocombustiveis/renovabio

Banja, M., Sikkema, R., Jégard, M., Motola, V., \& Dallemand, J. F. (2019). Biomass for energy in the EU - The support framework. Energy Policy, 131, 215-228. http://dx.doi.org/10.1016/j.enpol.2019.04.038.

Bizzo, W. A. (2017). Analysis of energy consumption in three systems for collecting sugarcane straw for use in power generation. Energy, 119, 178-187. https://doi.org/10.1016/j.energy.2016.12.067.

Câmara de Comercialização de Energia Elétrica - CCEE. (2021a). Electric energy trading. Retrieved in 2021, August 5, from https:// www.ccee.org.br/portal/faces/acesso_rapido_header_publico_nao_logado/biblioteca

Câmara de Comercialização de Energia Elétrica - CCEE. (2021b). Electric energy trading. Retrieved in 2021, August 5, from from https:// www.ccee.org.br/portal/faces/pages_publico/noticias-opiniao/noticias/

Christofoletti, C. A., Escher, J. P., Correia, J. E., Marinho, J. F. U., \& Fontanetti, C. S. (2013). Sugarcane vinasse: Environmental implications of its use. Waste Management (New York, N.Y.), 33(12), 2752-2761. http://dx.doi.org/10.1016/j.wasman.2013.09.005. PMid:24084103.

Dapeng, L., \& Weiwei, W. (2009). Barriers and incentives of CCS deployment in China: results from semi-structured interviews. Energy Policy, 376), 2421-2432. http://dx.doi.org/10.1016/j.enpol.2009.02.032.

Donner, M., Gohier, R., \& de Vries, H. (2020). A new circular business model typology for creating value from agro-waste. The Science of the Total Environment, 716, 137065. http://dx.doi.org/10.1016/j.scitotenv.2020.137065. PMid:32044489.

Dutra, J., \& Rodrigues, M. D. L. (2019). Distribuição de gás natural no Brasil: dados e aspectos regulatórios. São Paulo: FGV- Centros de Estudos em Regulação e Infraestrutura.

Empresa de Pesquisa Energética - EPE. (2020). Plano Decenal de Expansão de Energia 2029 (393 p.). Rio de Janeiro: MME/EPE. Retrieved in 2020, February 22, from http://www.epe.gov.br/pt/publicacoes-dados-abertos/publicacoes/plano-decenal-de-expansaode-energia-2029

Empresa de Pesquisa Energética - EPE. (2021). Brazilian Energy Balance 2021 Year 2020 (292 p.). Rio de Janeiro: MME/EPE.

Ferraresi, A. G. J., \& Calia, R. C. (2019). As barreiras de ampliação da bioeletricidade sucroenergética no Brasil: propostas políticas e econômicas para o setor. Caderno de Administração, 26(2), 75. http://dx.doi.org/10.4025/cadadm.v26i2.42765.

Frick, F. (2018). Efeito da adição fraccionada de bolo de filtro na digestão anaeróbica da vinhaça (Dissertação de mestrado). Universidade Federal do Paraná, Palotina.

Hughes, N., Mutran, V. M., Tomei, J., de Oliveira Ribeiro, C., \& Oller do Nascimento, C. A. (2020). Strength in diversity? Past dynamics and future drivers affecting demand for sugar, ethanol, biogas and bioelectricity from Brazil's sugarcane sector. Biomass and Bioenergy, 141, 105676. https://doi.org/10.1016/j.biombioe.2020.105676.

Janke, L., Leite, A., Nikolausz, M., Schmidt, T., Liebetrau, J., Nelles, M., \& Stinner, W. (2015). Biogas production from sugarcane waste: assessment on kinetic challenges for process designing. International Journal of Molecular Sciences, 16(9), 20685-20703. http:// dx.doi.org/10.3390/ijms160920685. PMid:26404248.

Leal, M. R. L. V., Galdos, M. V., Scarpare, F. V., Seabra, J. E. A., Walter, A., \& Oliveira, C. O. F. (2013). Sugarcane straw availability, quality, recovery and energy use: a literature review. Biomass and Bioenergy, 53, 11-19. http://dx.doi.org/10.1016/j.biombioe.2013.03.007.

López González, L. M., Pereda Reyes, 1., Dewulf, J., Budde, J., Heiermann, M., \& Vervaeren, H. (2014). Effect of liquid hot water pre-treatment on sugarcane press mud methane yield. Bioresource Technology, 169, 284-290. http://dx.doi.org/10.1016/j. biortech.2014.06.107. PMid:25062540.

López González, L. M., Vervaeren, H., Pereda Reyes, l., Dumoulin, A., Romero Romero, O., \& Dewulf, J. (2013). Thermo-chemical pretreatment to solubilise and improve anaerobic biodegradability of press mud. Bioresource Technology, 131, 250-257. http://dx.doi. org/10.1016/j.biortech.2012.12.167. PMid:23353040.

Lune, H., \& Berg, B. L. (2017). Methods for the social sciences, publications global edition (240 p.). England: Pearson Publication.

Mariani, L. (2018). Biogás: diagnóstico e propostas de ações para incentivar seu uso no Brasil (Tese de doutorado). Universidade Estadual de Campinas, Campinas. Retrieved in 2020, February 20, from https://www.saneamentobasico.com.br/wp-content/uploads/2020/05/ Mariani_Leidiane_D.pdf

Marvasti, B. A. (2004). Qualitative research in sociology: an introduction (169 p.). London: Sage Publication. http://dx.doi. org/10.4135/9781849209700.

Mathias, M. C. P. P., \& Mathias, J. F. C. M. (2015). Biogas in Brazil: a governmental Agenda. Journal of Energy and Power Engineering, 9(1), 1-15. http://dx.doi.org/10.17265/1934-8975/2015.01.001.

MegaWhat. (2019). A-6 auction: price per source. Retrieved in 2020, February 20, from https://megawhat.energy/analyses/1790

Mittal, S., Ahlgren, E. O., \& Shukla, P. R. (2018). Barriers to biogas dissemination in India: a review. Energy Policy, 112, 361-370. http:// dx.doi.org/10.1016/j.enpol.2017.10.027.

Moraes, B. S., Junqueira, T. L., Pavanello, L. G., Cavalett, O., Mantelatto, P. E., Bonomi, A., \& Zaiat, M. (2014). Anaerobic digestion of vinasse from sugarcane biorefineries in Brazil from energy, environmental, and economic perspectives: Profit or expense? Applied Energy, 113, 825-835. http://dx.doi.org/10.1016/j.apenergy.2013.07.018.

Nadaleti, W. C., Lourenço, V. A., Belli Filho, P., Dos Santos, G. B., \& Przybyla, G. (2020). National potential production of methane and electrical energy from sugarcane vinasse in Brazil: a thermo-economic analysis. Journal of Environmental Chemical Engineering, 8(2), 103422. http://dx.doi.org/10.1016/j.jece.2019.103422.

Neves, L. (2018). How to deliver at lower prices. Brasil Energia. Retrieved in 2020, January 20, from https://brasilenergia.editorabrasilenergia. com.br/

Pope, C., \& Ziebland, S. N. M. (2017). Qualitative research in health care - Analysing qualitative data. In J. E. Leestma, G. Harding, \& K. M. G. Taylor (Eds.), Pharmacy practice (2nd ed., pp. 455-466). https://doi.org/10.1201/b19093. 
Ramos, C. S. (2019). Endividamento das usinas cresceu em 2018/19. Valor Econômico. Retrieved in 2019, November 13, from https:// valor.globo.com/agronegocios/noticia/2019/11/13/endividamento-das-usinas-cresceu-em-2018-19.ghtml

Sales, C. J. D., \& Hochstetler, R. L. (2018). A crise do GSF: definição de Garantia Física de novas hidrelétricas (Partes 1 e II). Rio de Janeiro: Agência Canal Energia. Retrieved in 2021, August 8, from http://gesel.ie.ufrj.br/

União da Indústria de Cana-de-Açúcar - UNICA. (2019). A bioeletricidade da cana. Retrieved in 2020, Februay 20, from https://www. unica.com.br/wp-content/uploads/2019/07/UNICA-Bioeletricidade-julho2019-1.pdf

União da Indústria de Cana-de-Açúcar - UNICA. (2020). Bioelectricity. Retrieved in 2020, March 31, from https://unica.com.br/setorsucroenergetico/bioeletricidade/ 